Journal of Maternal and Child Health (2018), 3(2): 156-165

https://doi.org/10.26911/thejmch.2018.03.02.08

\title{
What are the Factors that Affect the Risk of Parenting Stress in Mothers with Disability Children? A New Evidence from Sukoharjo, Central Java
}

\author{
Syarifatul Fikriyyah'), Rita Benya Adriani'2), Bhisma Murti1) \\ ${ }^{1)}$ Masters Program in Public Health, Universitas Sebelas Maret \\ ${ }^{2)}$ School of Health Polytechnics Surakarta
}

\begin{abstract}
Background: Mothers play an important role in the care of children with physical and psychological disabilities. However, the role of caring children with disabilities can cause stress for the mother. Parenting stress can lead to anxiety, emotional instability, and avoidance of the environment in mother. This, in turn, may deteriorate the quality of family life. As a result, children with disabilities may experience development and growth disorders. This study aimed to determine the factors that affect the parenting stress in the caring of children with disability in Sukoharjo District, Central Java.

Subjects and Method: This was an analytic observational study with a cross-sectional design. The study was conducted at Sanggar Inklusi, Sukoharjo, Central Java, from February to March 2018. A sample of 163 mothers with disabled children was selected for this study by exhaustive sampling. The dependent variable was parenting stress. The independent variables were adversity intelligence, disability level, maternal education, maternal employment status, family income, and family support. The data were collected by questionnaire and analyzed by path analysis.

Results: The risk of maternal parenting stress increased with children disability $(b=4.64, \mathrm{SE}=$ $1.72, \mathrm{p}=0.07)$ and mothers working outside the house $(\mathrm{b}=1.68, \mathrm{SE}=0.93, \mathrm{p}=0.069)$. The risk of maternal parenting stress decreased with high adversity intelligence $(b=-0.28, S E=0.12, p=$ 0.016), high maternal education $(b=-8.50, S E=0.86, p<0.001)$, high family income $(b=-0.28$, $\mathrm{SE}=0.16, \mathrm{p}=0.078)$, and strong family support $(\mathrm{b}=-0.22, \mathrm{SE}=0.08, \mathrm{p}=0.007)$.

Conclusion: The risk of maternal parenting stress increases with high children disability and maternal employment status, but decreases with high adversity intelligence, high maternal education, high family income, and strong family support.
\end{abstract}

Keywords: parenting stress, children, disability

\section{Correspondence:}

SyarifatulFikriyyah. Masters Program in Public Health, Universitas Sebelas Maret, Jl. Ir. Sutami 36 A, Surakarta 57126, Central Java. Email: vivisyarifah@yahoo.com. Mobile: +6285642009597

\section{BACKGROUND}

People with disabilities are the world's largest minority. WHO in 2011 mentioned that there is about $15 \%$ of the world's population are persons with disabilities, meaning that 1 in 4 family members in one house are persons with disabilities (Ministry of Health, 2014).

Sukoharjo regency is one of the first inclusive districts in Indonesia to implement the Inclusive Village Program. The high number of people with disability becomes the background of the establishment of the Inclusion Studio in Sukoharjo District. This Inclusion Studio is one of the forms of community-based rehabilitation where services and rehabilitation are based on the role and empowerment of communities, community leaders, social organizations, NGOs, professional institutions, to help persons with disabilities meet their needs and rights. Currently, there are 4 Sanggar 
Inclusion in 4 sub-districts namely Wijaya Kusuma Inclusion Studio, Mutiara Bunda, Tunas Bangsa, and Anak Bangsa. The number of children with disabilities handled by inclusion centers is 163 children with disabilities (Profile of Sukoharjo District Social Service, 2015).

Parents generally expect the child's condition to be born healthy, but not all is in line with expectations. Difficulties and multiple barriers to disability children result in the stress of parental gratification (Hayes \& Watson, 2013).

Caring stress is more experienced by mothers than fathers. Research in Japan shows that the role of the mother as the closest person to the child has a tendency to experience parenting stress two times higher than the father's role in child care (Yamaoka et al., 2016).

Stress in mothers with children with disabilities results in increased anxiety, emotional instability and avoidance of environmental reactions that lead to a deterioration in the quality of family life (Lara and de los Pinos, 2017). The limited ability of mothers in finding information and knowledge to handle the problems of children with disabilities cause stress on the mother. Mothers need a great effort to cope with every issue of care for their children with disabilities. The ability to deal with life's problems is called adversity. The caring process has an important component that cannot be separated from social support, especially the support of a spouse or husband (Isa et al., 2016).

Husband's support will improve the welfare and adaptation of mothers with children with disabilities. A study conducted by $\mathrm{Ki}$ and Joane (2014) shows that good cooperation between husband and wife can reduce the stress of parenting (Ki \& Joanne, 2014). Research in Japan states that single parent mothers with children with dis- abilities have higher stress levels than mothers with partners in caring for children (Yamaoka et al., 2016).

A study conducted in the United States in 2015 shows that family support has a significant influence on nursing stress. High family support has an impact on the quality of a good marital relationship resulting in low parenting stress levels (Mitchell et al., 2016). The researchers concluded from the above research that family support has an influence on maternal stress levels in the mother. Strong family support will reduce the stress of parenting in mothers with children with disabilities.

Needs of children with disabilities are more than normal children's needs, because children with disabilities have many obstacles in some aspects of development that require therapy, facilities and infrastructure and treatment that is longer and even lifetime. This will have an impact on the high economic burden of the family because it has to spend a lot of money for the needs of children with disabilities (Azeem et al., 2013).

Needs which are not fulfilled will have an impact on the emotional state of family members. The Sinai \&Tikotzky (2012) study that examined maternal sleep patterns with maternal stress on working moms and working moms taking a leave showed that working mothers had higher levels of stress with poor sleep quality. The researchers concluded that working mothers had a higher degree of parental stress than those who did not work (Sinai and Tikotzky, 2012).

Children with multiple disability types have a higher risk of parenting stress than children with a single type of disability. Children with dual disabilities have an influence on the level of parenting stress in the elderly, especially on the mother. Mothers with children with dual disabilities 
Journal of Maternal and Child Health (2018), 3(2): 156-165

https://doi.org/10.26911/thejmch.2018.03.02.08

have a higher stress level than mothers with single children with disabilities (Craig et al., 2016).

Provision and health services in Sukoharjo District have only focused on people with disabilities and exclude the role of parents, especially mothers, though the role of mothers has a greater burden in the care of children with disabilities both physically and psychologically. This will disrupt the process of development and growth of children especially in children with disabilities that require more care. This problem is what makes the researchers interested to conduct a study under the topic of "Factors Affecting Maternal Stress with Disabled Children in Sukoharjo District Inclusion Studio" and is expected to provide new evidence about the stress of care.

\section{SUBJECTS AND METHOD \\ 1. Study design \\ This was an analytic observational study with a cross sectional design. The study was conducted in Sanggar Inklusi, Sukoharjo, Central Java, from February to March 2018.}

\section{Population and samples}

The target population in this study was all mothers with children with disabilities. Source population in this study is mothers who have children with disability in Sanggar Inklusi Sukoharjo District. The number of samples in this study was 163 subjects. The sampling technique was done using total sampling technique. The inclusion criteria in this study were mothers with children with disabilities aged $\leq 18$ years old and not illiterate. Exclusion criteria of this study were mothers who did not complete the questionnaire and who have severe mental disorder.

\section{Study variables}

In this study endogenous variables consist of stress parenting, family income, adversity intelligence and husband support. The exo- genous variables were education, employment, husband support, disability level and family support.

\section{Operational definition of variable}

Nurture stress was defined as the condition of the maternal role function in the parenting process and the interaction with the child which is unbalanced, causing conflict and resulting a negative response on the mother. The data were collected by Parenting Stress Index questionnaire. The measurement scale was continuous, but for the purpose of data analysis, it was transformed into dichotomous, coded o for low stress (score $<75$ ) and high stress (score $\geq 75$ ).

The adversity intelligence was defined as an ability to measure maternal resilience when faced with problems and difficult situations in having children with disabilities. The data was measured by Adversity Response Profile questionnaire. The measurement scale was continuous, but for the purpose of data analysis, it was transformed into dichotomous, coded o for low adversity intelligence (score <61) and 1 for high adversity intelligence (score $\geq 61$ ).

Husband support was defined as the presence of a husband who is trustworthy, caring, giving attention and assistance to the wife who plays a role as a mother with children with disabilities. The measurement scale was continuous, but for the purpose of data analysis, it was transformed into dichotomous, coded o for weak husband support and 1 for strong husband support.

Family support was defined as the presence of members of the family and relatives who still have blood relatives who pay attention and assistance to mothers with children with disabilities. The measurement scale was continuous, but for the purpose of data analysis, it was transformed into dichotomous, coded o for weak family support and 1 for strong family support. 
Education was defined as the highest level of formal educatio pursued by mothers. The measurement scale was categorical.

Family income was defined as the amount of income from family member's house in 1 month expressed in rupiah. The measurement scale was continuous.

Employment status was defined as the position of mother with child with disability in doing work in an agency or business unit in order to earn income. The measurement scale was categorical.

Disability level was defined as the number of child disabilities. The data were collected by questionnaires. The measurement scale was categorical.

\section{Data analysis}

Data analysis used in this studywas path analysis, conducted using SPSS AMOS 22 program to know the effect of variable, either directly or indirectly. The steps of path analysis were model specification,

Table 1. The Characteristics of Subjects

\begin{tabular}{llcc}
\hline Characteristics & Criteria & $\mathbf{N}$ & $\mathbf{\%}$ \\
\hline Education & Primary school & 17 & 10.4 \\
& Junior high school & 44 & 27.0 \\
& Senior high school & 73 & 44.8 \\
& Diploma & 13 & 8.0 \\
Occupation & Bachelor & 16 & 9.8 \\
& Working outside the house & 107 & 65.6 \\
& Entrepreneur & 20 & 12.3 \\
Family Income & Farmer & 26 & 16.0 \\
& Civil Servant & 10 & 6.1 \\
Type of disability & Low & 59 & 36.2 \\
& High & 104 & 63.8 \\
& Single & 79 & 48.5 \\
\hline
\end{tabular}

Descriptive statistics of continuous data in the form of education level, employment status, family income, disability type, adversity intelligence, family support, husband support and nursing stress can be seen in Table 2.

Table 2 shows descriptive statistics of each variable including median, standard deviation, minimum and maximum to model identification, model fit, parameter estimation, and model re-specification.

\section{Research Ethics}

The research ethics included informed consent by the subjects, anonymity, confidentiality and ethical clearance. The ethical clearance in this study was conducted in Dr. Moewardi hospital, Surakarta, Central Java.

\section{RESULTS}

The characteristics of subjects in this study were seen based on the education level, employment status, family income and disability level. Research subjects in this study were 163 mothers with children with disabilities in Sanggar Inkusi, Sukoharjo. Table 1 shows that out of 163 study subjects, $44.8 \%$ of mothers are high school graduates, $65.5 \%$ of mothers are unemployed, families have income $\geq \operatorname{Rp~1,500,000.00,~and~there~}$ were $51.5 \%$ children with disabilities double. 
the SD value is very small compared to the median value, then the median value can be used as a representation of the whole data. Table 2 shows the measurement of the variables of education level, employment status, family income, adversity intelligence, husband support, family support, and nursing stress have a standard deviation value well below the median value.

Table 2. Univariate Analysis

\begin{tabular}{lccccc}
\hline \multicolumn{1}{c}{ Variable } & n & Median & SD & Min. & Max. \\
\hline Education & 163 & 3 & 1.061 & 1 & 5 \\
Occupation & 163 & 1 & 0.963 & 1 & 4 \\
Family Income (Rupiah) & 163 & 15 & $5 \cdot 759$ & 9 & 4 \\
Type of disability & 163 & 1 & 0.501 & 0 & 1 \\
Adversity Intelligence & 163 & 61 & 7.518 & 45 & 72 \\
Husband Support & 163 & 76 & 10.712 & 45 & 96 \\
Family Support & 163 & 67 & 7.829 & 40 & 80 \\
Parenting stress & 163 & 75 & 15.647 & 34 & 100 \\
\hline
\end{tabular}

Table 3. The results of bivariate analysis using Pearson correlation

\begin{tabular}{lcc}
\hline \multicolumn{1}{c}{ Independent Variable } & Pearson Correlation (r) & p \\
\hline Education & -0.65 & $<0.001$ \\
Occupation & 0.21 & 0.007 \\
Family Income & -0.21 & 0.007 \\
Type of Disability & 0.16 & 0.039 \\
Adversity Intelligence & 0.001 & $<0.001$ \\
Husbands' Support & -0.12 & 0.013 \\
Family Support & -0.20 & 0.011 \\
\hline
\end{tabular}

Table 3 shows that education level has $\mathrm{r}=-0.65$ and $\mathrm{p}=<0.001$. This suggests that education has a negative effect on maternal stress and is statistically significant. A high level of maternal education will make the level of parenting stress lower than that of a low educated mother. The maternal employment status has a value of $r=0.21$ and the value $p=0.007$. This suggests that the status of work has a positive effect on parenting stress. Mothers who work outside the home have a higher level of parenting stress than mothers working at home.

Family income has $\mathrm{r}=-0.21$ score and $\mathrm{p}=0.007$ score. Family income has a negative effect on parenting stress. High level of family income would decrease the parenting stress in mothers. Disability type has $r=0.16$ and $p=0.039$. This type of disability has a positive effect on parenting stress. Mothers with multiple disabilities children have a higher stress level than mothers with single disability children. Adversity intelligence with $r=0.001$ score and $\mathrm{p}<0.001)$ score has a positive and statistically significant effect. If the level of mothers' adversity intelligence was high, then it would decrease the level of maternal stress. Husband's support has $\mathrm{r}=-0.12$ and $\mathrm{p}=0.013$. Husband's support has a negative effect on parenting stress. Strong husbands' support would lead to low maternal stress levels than low support from husbands. Family support has $r=-0.20$ and $p=0.011$. Family support has a negative effect on parenting stress. Strong family support would decrease maternal stress levels than mothers with low family support. 
Fikriyyah et al./ What are the Factors that Affect the Risk of Parenting Stress

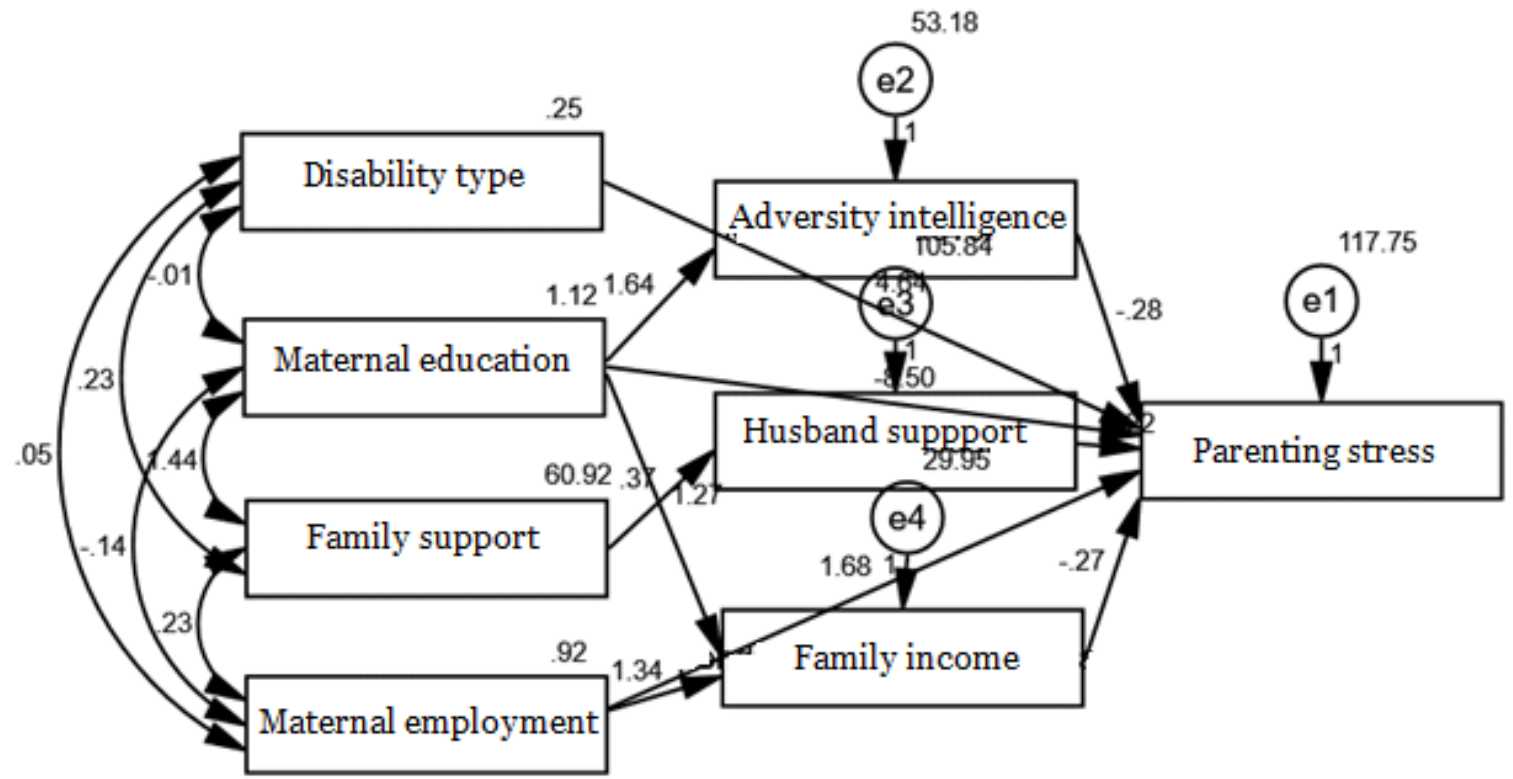

Figure 1. Structural model of path analysis

Table 4.Path analysis results about the effect of education, employment status, family income, disability type, adversity intelligence, husband support, and family support on parenting stress

\begin{tabular}{|c|c|c|c|c|c|c|}
\hline \multirow{2}{*}{\begin{tabular}{|c|c}
$\begin{array}{c}\text { Dependent } \\
\text { Variable }\end{array}$ \\
Direct effect
\end{tabular}} & \multicolumn{2}{|c|}{$\begin{array}{l}\text { Independent } \\
\text { Variable }\end{array}$} & b & \multirow[t]{2}{*}{ SE } & \multirow[t]{2}{*}{$\mathbf{p}$} & \multirow[t]{2}{*}{$\boldsymbol{\beta}$} \\
\hline & & & & & & \\
\hline Parenting Stress & \multicolumn{2}{|c|}{$\leftarrow$ Disability Type } & 4.64 & 1.72 & 0.007 & 0.15 \\
\hline Parenting Stress & \multicolumn{2}{|c|}{$\leftarrow$ Employment } & 1.68 & 0.93 & 0.069 & 0.10 \\
\hline Parenting Stress & \multicolumn{2}{|c|}{$\leftarrow$ Husband Support } & -0.22 & 0.08 & 0.007 & -0.15 \\
\hline Parenting Stress & \multicolumn{2}{|c|}{$\leftarrow$ Education } & -8.50 & 0.86 & $<0.001$ & -0.58 \\
\hline Parenting Stress & \multicolumn{2}{|c|}{$\leftarrow$ Adversity Intelligence } & -0.28 & 0.12 & 0.016 & -0.14 \\
\hline Parenting Stress & \multicolumn{2}{|c|}{$\leftarrow$ Family Income } & -0.28 & 0.16 & 0.078 & 0.10 \\
\hline \multicolumn{7}{|l|}{ Indirect effect } \\
\hline Husband Support & \multicolumn{2}{|c|}{$\leftarrow$ Family Support } & 0.37 & 0.10 & $<0.001$ & 0.27 \\
\hline Family Income & \multicolumn{2}{|c|}{$\leftarrow$ Education } & 1.27 & 0.41 & 0.002 & 0.24 \\
\hline Adversity Intelligence & \multicolumn{2}{|c|}{$\leftarrow$ Education } & 1.64 & 0.54 & 0.003 & 0.23 \\
\hline Family Income & \multicolumn{2}{|c|}{$\leftarrow$ Employment } & 1.34 & 0.45 & 0.003 & 0.22 \\
\hline \multicolumn{7}{|l|}{$\mathrm{N}$ observation $=163$} \\
\hline \multicolumn{7}{|l|}{ Fit Model } \\
\hline \multirow{2}{*}{\multicolumn{2}{|c|}{$\begin{array}{l}b=\text { Unstandarized Path Coefficients } \\
\beta=\text { Standarized Path Coefficients }\end{array}$}} & NFI & $=0.946$ & & & \\
\hline & & CFI & $=1.000$ & & & \\
\hline \multicolumn{2}{|l|}{$\mathrm{CMIN}=9.461$} & RMSEA & $=0.000$ & & & \\
\hline
\end{tabular}

Figure 1 showed the structural model after the estimation using IBM SPSS AMOS 22 in order to obtain the values provided in the picture. Indicator that showed the suitability of path analysis model in table 4 which also showed the goodness of fit measure that got result of CMIN fit index by 9.461 with score $\mathrm{p}=0.663>0.05 ; \mathrm{GFI}$ (Goodness of Fit Index) $=0.985 \geq 0.90$; NFI (Normed Fit Index) $=0.946 \geq 0.90$; 
CFI (Comparative Fit Index) $=1.00 \leq 0.90$; RMSEA (Root Mean Square Error of Approximation) $<0.001 \geq 0.08$ which mean that the empirical model met the specified criteria and was determined according to the empirical data.

Table 4 showed the results of path analysis of the effect of education, employment status, family income, disability type, adversity intelligence, husband support, family support, and parenting stress.

Parenting stress was directly and positively affected by disability type $(b=$ 4.64, $\mathrm{SE}=1.72, \mathrm{p}=0.007$ ) and maternal employment status $(b=1.68, \mathrm{SE}=0.93, \mathrm{p}=$ 0.069).

Parenting stress was directly and negatively affected by husband support $(b=-$ 0.22, $\mathrm{SE}=0.08, \mathrm{p}=0.007)$, education $\geq$ Senior high school $(\mathrm{b}=-8.50, \mathrm{SE}=0.86, \mathrm{p}=$ $<0.001)$, adversity intelligence $(b=-0.28$, $\mathrm{SE}=0.12, \mathrm{p}=0.016)$ and family income $(\mathrm{b}=-$ $0.28, \mathrm{SE}=0.16, \mathrm{p}=0.078$ ).

Husband support increased with family support $(b=0.37, \quad S E=0.10, p$ <0.001). Family income increased with education $\geq$ Senior high school $(b=1.27, S E=$ $0.41, \mathrm{p}=0.002$ ) and mother working outside the house $(b=1.34, \mathrm{SE}=0.44, \mathrm{p}=0.003)$. Adversity intelligence increased with maternal education $(b=1.64, \mathrm{SE}=0.54, \mathrm{p}=$ o.003).

\section{DISCUSSIONS \\ 1. The Effect of Maternal Educational Level on Parenting Stress.}

The result of analysis showed that there was indirect and negative effect of maternal educational level on parenting stress. Parenting stress was influenced by indirect maternal education through family income and adversity level of intelligence. High educational level increased the family income and adversity intelligence but decreased the stress levels of parenting.
A study in Scotland found that mothers with low educational levels were at risk of experiencing parenting stress by two times greater than mothers with high level of education (Parkes et al., 2015). This was related to the lack of professional support received by mothers with low education due to low economic status.

Mothers with low levels of education have six times higher risk of experiencing parenting tress (Deniz-Can and GinsburgBlock, 2016).

\section{The Effect of Employment Status on Parenting Stress.}

The result of analysis showed that maternal employment status has a direct and indirect effect on parenting stress. The indirect effect of maternal employment status on parenting stress was through family income.

Mothers who work outdoors have a higher parenting stress than mothers who work at home. A study by Nomaguchi and House (2013) showed that $57 \%$ of mothers who work outside the house have a higher level of parenting stress than mothers who work at home. Mothers have to worked outside the house because their husband have unfixed job so that family income was not sufficient for family needs (Nomaguchi and House, 2013).

Stress level of maternal parenting which was investigated by Sinai and Tikotzy (2012) through sleep patterns indicated that working mothers have poor sleep patterns. This was because maternal burden was more than the mother who worked at home.

\section{The Effect of Family Income on Parenting Stress.}

The result of analysis showed that there was a negative and direct effect of family income on parenting stress. The higher family income, the lower the parenting stress. The needs of families who have family members with disabilities were more than normal family members. 
A study by Azeem et al. (2013) showed thatlow income families have little opportunity to fulfill the family needs, while children with disabilities have more needs. This resulted in higher parenting stress in families with low incomes (Azeem et al., 2013). Research in the United States found that low-income families had four times higher risk of parenting stress than families with high family income (Zalewski et al., 2012).

\section{The Effect of Disability Types on Parenting Stress}

The result of analysis showed that disability types has a positive and direct effect on parenting stress. Mothers who have children with multiple disability types had higher levels of parenting stress than mothers who have children with a single type of disability. Children with multiple disabilities have more limitations and disruptions. This required more care and attention from mothers than children with single disability. Therefore, parenting stress experienced by mothers who have children with multiple disabilities was higher than mothers who have children with single disability.

Research in the United States showed that stress levels of parenting who have children with multiple disabilities (ASD and ADHD) were higher than children with single disability (Craig et al., 2016). The result of a study by Almogbel et al. (2017) stated thatparenting stress in parents who have children with multiple disabilities was 5.5 times higher than parents who have children with single disability (Almogbel et al., 2017).

\section{The Effect of Adversity Intelligence on Parenting Stress.}

The result of analysis showed that adversity intelligence has a negative and direct effect on parenting stress. The higher the maternal adversity intelligence, the lower the parenting stress. Mothers need a great effort to face every parenting problem for their children with disabilities. Adversity intelligence was the ability of mothers to face problems and survive and also overcome the difficulties which in this case was having children with disabilities (Tian and Fan, 2014).

Adversity intelligence has a direct effect on maternal parenting stress as stated in a study by Ratnani (2014) which stated that adversity intelligence factor has $53.8 \%$ effect on parenting stress. A study in Thailand revealed that teenagers who came from families with unresponsive parent and child interactions have a low score in each dimension of adversity intelligence (Yakoh et al., 2015).

\section{The Effect of Husband Support on Parenting Stress.}

The result of analysis showed that husband support has a negative and direct effect on parenting stressand it was statistically significant. Mothers with high husbands support have low levels of parenting stress. The parenting process has an important component that cannot be separated from social support, especially the support of spouses or husbands (Isa et al., 2016).

Husband support would mprove the welfare and adaptation of mothers who have children with disabilities. A study by Ki and Joane (2014) stated that good cooperation between husband and wife could reduce the stress of parenting. Study in Japan stated that single parent mothers who have children with disabilities have higher levels of stress than mothers who have partners in parenting (Yamaoka et al., 2016).

\section{The Effect of Family Support on Parenting Stress.}

The result of analysis showed that family support has a negative and indirect effect on parenting stress. Family support was also indirectly affected to parenting stress through husband support. 
Journal of Maternal and Child Health (2018), 3(2): 156-165

https://doi.org/10.26911/thejmch.2018.03.02.08

A study in India stated that high family support would reduce the stress of parenting in mothers who have children with mental disabilities (Das et al., 2017). A study in the United States in 2015 showed that family support has a significant influence on parenting stress. High family support has an impact on the quality of a good marriage relationship so that the level of parenting stress was low (Mitchell et al., 2016).

The results of this study concluded that family support has an effect on maternal parenting stress. Strong family support would decrease parenting stress among mothers who have children with disabilities.

\section{REFERENCES}

Almogbel YS, Goyal R, Sansgiry SS (2017). Association Between Parenting Stress and Functional Impairment Among Children Diagnosed with Neurodevelopmental Disorders. Community Mental Health Journal, 53(4), 405414. https://doi.org/10.1007/s10597017-0096-9

Azeem MW, Dogar IA, Shah S, Cheema MA, Asmat A, Akbar M, et al. (2013). Anxiety and Depression among Parents of Children with Intellectual Disability in Pakistan. Journal of the Canadian Academy of Child and Adolescent Psychiatry $=$ Journal de l'Académie Canadienne de Psychiatrie de L'enfant et de L'adolescent, 22(4), 290-295.

Craig F, Operto FF, De Giacomo A, Margari L, Frolli A, Conson M, et al. (2016). Parenting stress among parents of children with Neurodevelopmental Disorders. Psychiatry Research, 242, 121-129. https://doi.org/10.1016/j.psychres.2016.05.016

Das S, Das B, Nath K, Dutta A, Bora P, Hazarika $M$ (2017). Impact of stress, coping, social support, and resilience of families having children with autism: A North East India-based study. Asian Journal of Psychiatry, 28, 133-139. https://doi.org/10.1016/j.ajp.2017.03.040

Deniz Can D, Ginsburg-Block M (2016). Parenting stress and home-based literacy interactions in low-income preschool families. Journal of Applied Developmental Psychology, 46, 51-62. https://doi.org/10.1016/j.appdev.2016 .07 .002

Hayes SA, Watson SL (2013). The impact of parenting stress: A meta-analysis of studies comparing the experience of parenting stress in parents of children with and without autism spectrum disorder. Journal of Autism and Developmental Disorders, 43(3), 629642. https://doi.org/10.1007/s10803012-1604-y

Isa SNI, Ishak I, Ab Rahman A, Mohd Saat NZ, Che Din N, Lubis SH, Mohd IMF. (2016). Health and quality of life among the caregivers of children with disabilities: A review of literature. Asian Journal of Psychiatry, 23(2016), 71-77. https://doi.org/10.1016/j.ajp.2016.07.007

Kementrian Kesehatan RI. (2014a). Kabupaten Sukoharjo Tahun 2014.

(2014b). Situasi Penyandang Disabilitas. Buletin Jendela Data \& Informasi Kesehatan, Semester 2(1), 1-5. https://doi.org/10.1007/s13398014-0173-7.2

Ki YW, Joanne CCY (2014). Stress and Marital Satisfaction of Parents with Children with Disabilities in Hong Kong. Psychology, 5(5), 349-357. https://doi.org/10.4236/psych.2014.5 5045 .

Lara EB, de los Pinos CC (2017). Families with a Disabled Member: Impact and Family Education. Procedia - Social 
and Behavioral Sciences, 237(June 2016), 418-425. https://doi.org/10.1016/j.sbspro.2017.02.084.

Mitchell DB, Szczerepa A, Hauser-Cram P (2016). Spilling over: Partner parenting stress as a predictor of family cohesion in parents of adolescents with developmental disabilities. Research in Developmental Disabilities, 49-50, 258-267. https://doi.org/10.1016/j.ridd.2015.12.007.

Nomaguchi K, House AN (2013). RacialEthnic Disparities in Maternal Parenting Stress: The Role of Structural Disadvantages and Parenting Values. Journal of Health and Social Behavior, 54(3), 386-404. https://doi.org/10.1177/0022146513498511.

Parkes A, Sweeting H, Wight D (2015). Parenting stress and parent support among mothers with high and low education. Journal of Family Psychology, 29(6), 907-918. https://doi.org/10.1037/famoooo129.

Sinai D, Tikotzky L (2012). Infant sleep, parental sleep and parenting stress in families of mothers on maternity leave and in families of working mothers. Infant Behavior and Development, 35(2), 179-186. https://doi.org/10.1016/j.infbeh.2012.01.006.
Tian Y, Fan X (2014). Adversity quotients, environmental variables and career adaptability in student nurses. Journal of Vocational Behavior, 85(3), 251257. https://doi.org/10.1016/j.jvb.2014.07.006.

Yakoh M, Chongrukasa D, Prinyapol P (2015). Parenting Styles and Adversity Quotient of Youth at Pattani Foster Home. Procedia - Social and Behavioral Sciences, 205: 282-286. https://doi.org/10.1016/j.sbspro.2015.09.078.

Yamaoka Y, Tamiya N, Izumida N, Kawamura A, Takahashi H, Noguchi $H$ (2016). The relationship between raising a child with a disability and the mental health of mothers compared to raising a child without disability in japan. SSM - Population Health, 2, 542-548. https://doi.org/10.1016/j.ssmph.2016.08.001.

Zalewski M, Lengua LJ, Kiff CJ, Fisher PA. (2012). Understanding the relation of low income to HPA-axis functioning in preschool children: Cumulative family risk and parenting as pathways to disruptions in cortisol. Child Psychiatry and Human Development, 43(6), 924-942. https://doi.org/10.1007/s10578-012-0304-3. 